\title{
Organic-carbon burial, climate change and ocean chemistry (Mesozoic-Palaeogene)
}

\author{
HELEN S. MORGANS-BELL ${ }^{1} \&$ ANTHONY S. COHEN ${ }^{2}$ \\ ${ }^{1}$ Department of Earth Sciences, University of Oxford, Parks Road, Oxford OX1 3PR, UK (e-mail: helenm@earth.ox.ac.uk) \\ ${ }^{2}$ Department of Earth Sciences, The Open University, Walton Hall, Milton Keynes MK7 6AA. UK
}

This thematic set brings together a selection of papers that were presented at a conference entitled 'Organic-Carbon Burial, Climate Change and Ocean Chemistry (Mesozoic-Palaeogene)' at the Geological Society of London, 9-11 December 2002. The conference, informally known as 'the Black Shales Meeting', was convened by Hugh Jenkyns, Juergen Thurow and Tom Wagner. It attracted over 100 scientists from 15 different countries, proving that current research into Black Shales is highly active. Twenty-seven talks were given during the meeting, and some 40 posters were also presented. Although the nine papers that are published here represent a relatively small part of the large number of topics that were discussed, we nevertheless hope that they reflect the diversity and far-reaching nature of the research that is currently being carried out on 'Black Shales'.

Whilst Mesozoic Black Shales have enormous economic significance as hydrocarbon source rocks, the emphasis of the December 2002 meeting was on the importance of Black Shales and associated lithologies as palaeoenvironmental indicators in the broadest sense. This importance comes about because individual Black Shale samples can contain a wide variety of records of prevailing ocean chemistry, while Black Shale successions - which are often stratigraphically complete, undisturbed, and available for study at a relatively high resolution - can reflect longer-term temporal changes in palaeoenvironmental conditions.

It is over 20 years since the first international conference on Black Shales took place, on 5 May 1979, at the Geological Society of London (Hallam 1980). That conference was held at a time when the recent discovery of black carbon-rich rocks in deep-sea drilling sites from the Atlantic, Indian and Pacific Oceans had led to the concept of Oceanic Anoxic Events (Schlanger \& Jenkyns 1976). Schlanger \& Jenkyns' seminal work provided an explanation for the widespread (and perhaps global) distribution of organic-rich rocks that has occurred at certain key times of Earth history, and it paved the way for much of the research in this area that has since been carried out. The wide range of stratigraphical, sedimentological and geochemical techniques has been developed over the last 20 years or so that enable us to take advantage of the unique 'information database' that is stored within these successions. Today, the analysis of the stable isotopes of $\mathrm{C}$ and $\mathrm{O}$ is now used widely in assessing past changes in the carbon cycle and in seawater temperatures, while the development of new stable isotope systems such as S, N and Fe have the potential to provide further insights. Additionally, compound-specific C-isotope analysis is now able to avoid some of the problems imposed by the averaging effect associated with the use of bulk organic matter. The radiogenic isotope analysis of $\mathrm{Sr}$ and, more recently, of Os is proving to be particularly powerful in providing information on fluctuations in volcanism, climate and weathering during the Mesozoic. Wide acceptance of Milankovitch theory has revolutionized our understanding of the sedimentary record and of some of the fundamental causes of climate change, whilst cyclostratigraphic techniques, which are often used in conjunction with modern instrumental and geochemical methods, provide the basis for establishing timescales of the highest resolution.

The thematic set begins with three papers on the Kimmeridge Clay Formation at its type section in Dorset, southern England. These papers represent part of a collaborative study to understand the principal controls on sediment deposition at an important time of petroleum source-rock formation. Although these contributions focus on data collected from the Wessex Basin, their results have far broader implications. The article by Weedon $\boldsymbol{e t}$ al. provides a spectral analysis of the metre-scale sedimentary cycles that comprise the formation. Using their new timescale for the Kimmeridgian Stage (sensu anglico), the authors estimate organic productivity in the Late Jurassic epeiric seaway in which the formation was deposited. In the subsequent paper, Tyson estimates variations in organic matter content through the Kimmeridge Clay Formation. He concludes that dilution may have been a significant controlling variable on the accumulation of organic matter, and that palaeoproductivity levels were likely to have been appreciably lower than those in present-day shelf settings. Pearson et al. present a high-resolution study of laminae-scale variations in palynology and geochemistry that characterize the coccolith-rich White Stone Band, a prominent bed that crops out in Dorset and has been recovered from boreholes as far north as Yorkshire. These authors propose that late-season storms may have played an important role in mixing terrestrial with marine debris, leading to the intercalation of thin organic-rich layers within the metre-scale coccolith-rich succession.

The papers that follow concentrate on the integration of highresolution geochemical records with detailed biostratigraphy. The paper by Mattioli et al. describes temporal variations in calcareous and organic phytoplankton across western Tethys during the Toarcian. The authors relate stratigraphical changes in the nannoplankton community to concomitant magmatic activity that is thought to have been amplified by transient methane release, possibly acting as a trigger for a biocalcification crisis. The following contribution by Weissert \& Erba also investigates causes of biocalcification crises in western Tethys, in this case across the Late Jurassic-Early Cretaceous boundary, enabling the authors to conclude that such crises can be related to fluctuations in $p \mathrm{CO}_{2}$, nutrient availability and the temperature of surface waters.

The focus of the papers then shifts from the Jurassic and Early Cretaceous of western Tethys to the mid-Cretaceous in the Ionian Zone of NW Greece. Danelian et al. present micropalaeontological and geochemical data from a poorly known interval in Greece that they correlate with OAE1a (the Selli Event) in Italy, thus providing evidence for an oceanic connection between Greece and areas of Tethys further west. The fact that overlying radiolarite deposits are more restricted geographically suggests that, despite this connection, periods of upwelling may have been localized in occurrence. The subsequent paper by Tsikos $\boldsymbol{e t}$ al. 
presents a new, detailed chemostratigraphic framework for OAE2 (the Bonarelli Event), incorporating sections from England, Italy and Morocco. The authors suggest that the event is mostly, if not entirely, confined to the latest Cenomanian.

The penultimate paper, by Nederbragt et al., outlines a theoretical consideration of the factors controlling carbon and phosphorous fluxes during the late Cenomanian; the authors conclude that a perturbation in the oceanic phosphorous cycle led to the occurrence of OAE2. The final paper is by Cohen, who presents an overview of how osmium-isotope geochemistry has contributed to our understanding of some of the major episodes of environmental change in the Mesozoic. In two of the examples (the Triassic-Jurassic boundary and the Toarcian oceanic anoxic event), the isotopic evidence suggests that environmental change was intimately linked to the large-scale eruption of continental flood basalts and to the destabilization of large quantities of gas hydrate.
The meeting could not have taken place without generous support received from the Natural Environment Research Council, Statoil, TotalElfFina, Shell, BP, the Ocean Drilling Program and the Marine Studies Group. We are also indebted to many colleagues for their help in reviewing the manuscripts submitted for the volume, including T. Adatte, L.J. Clarke, A.L. Coe, J.R. Disnar, E. Erba, P. Farrimond, K. Föllmi, A. Gale, R. Gallois, M. Hart, F. Hilgen, L. Hinnov, J.D. Hudson, I. Jarvis, H.C. Jenkyns, G. Keller, J. Lees, E. Mattioli, A. Montanari, A.J. Nederbragt, R.D. Pancost, G. Price, J. Riding, A. Ruffell, B. Schaefer, F. Surlyk, S. Turgeon, R.V. Tyson, B. van Dongen, T. Wagner, G.P. Weedon, H. Weissert, P.B. Wignall and P.A. Wilson.

\section{References}

Hallam, A. 1980. Black Shales. Journal of the Geological Society, London, 137, $123-124$.

Schlanger, S.O. \& Jenkyns, H.C. 1976. Cretaceous oceanic anoxic events: causes and consequences. Geologie Mijnbouw, 55, 179-184. 